感作リンパ球の動態に関する研究

\author{
第 2 編 \\ 感作リリパ球の寿命 \\ 岡山大学医学部第 1 解剖学教室 (指導 : 尾曽越文亮教授) \\ 岡山大学医学部整形外科学教室 (指導 : 児玉 俊夫教授)
}

大学院学生山本明信

[昭和40年12月25日受稿]

\section{I. 粕}

第 1 編において， マウスをウシの アジュバントを用いて感作すると，領域リンパ節に リン八゚球の著明な增殖反応がおこり，トリチウム． チミジンをとりこむリンパ球の百分比が急激に上昇 することを確認した。このように抗原刺激によつて 増殖したリンパ球は，すべて感作されたリンパ球と みなして差支えないわけであるが、リンパ球は抗原 刺激ばかりでなく、非抗原性物質特に Freund の不 完全アジュバト (incomplete Freund's adjuvant) に対してすかなり著しい増殖反応をあらわす（尾曾 越 19641)，19652-4)）ので，てれによつて増殖した リンパ球は抗原に反応して増殖した真の感作リンパ 球とは区別されねばならぬ。ささらに，真の感作リン 八球のうちには，免度情報を保持しながら長期間静 止状態にある(すなわち寿命の長い)，いわゆる゙免 发学的記憶稩胞” (immunological memory cell8)の 役割を果するのがあることが期待される.

本研究は，感作リンパ球のうちで，とく佂長期間 残存する（すなわち寿命の長い）田のの数が, 特定 の】つの抗原に対応してどれだけ出現するかを明ら かにし，それと免疫学的記憶細胞との関係を考察し ようとするあのである.

\section{II. 実 臨 方 法}

実匬動物：実験動物はすべて岡山大学医学部マウ スコロニ一保存の均一系 DB マウスである. 実験に さきだち，標準食 (オリエンタル実験用固型飼料) をあつて1週間以上飼育し, 体重が着実に増加しつ つあるととを確め,体重がほほ20 g に達したマウス (雙堆両性) 51匹を選んで実験に共した. マウスを 3 群に分け, 第 1 群には21匹, 第 2 群と第 3 群には
それぞれ15匹ずつ使用した。

感作方法：抗原としては, 第 1 糄に垠告した実験 におけると同様に，ウシの Gamma Globulin Fraction II : Nutritional Biochemical Corporation, Cleveland, Ohio, U.S.A.) (以下 BGG と略記）を用いた，第 1 群（マウス21匹）に対 しては, BGG $3 \mathrm{mg}$ を含む $0.4 \mathrm{ml}$ の生理的生塩水 と Freund の完全アシュバント (complete Freund's adjuvant: Difco haboriatories, Detroit, michigan, U.S. A.)の0.4mlとをよく湿合，油中水滴の孚剂として体 幹皮下 4 個所に分割注射した。第 2 群(マウス15匹) には，Freund の完全アジハハント $0.4 \mathrm{ml}$ を単独に， $.4 \mathrm{ml}$ の生理 的食塩水之混合して, 同じく油中水滴 の乳剂として注射した，第 3 群 (マウス15匹)には， $0.8 \mathrm{ml}$ の生理的食塩水のみを注射して対照とした . トリチウム・チミジンによる標識付け : 上述の 3 群のマウスは，いずれす抗原注射後 $5,6,7$ 日目 の3 日間,トリチウム・チミジン ( ${ }^{3}$ H-thymidine: Radiochemical Center, Amersham, England. 5000 $\mathrm{mc} / \mathrm{mM}$ ) (以下 TTH と略記)を体重 $1 \mathrm{~g}$ あたり 0.5 $\mu \mathrm{c}$ の割合で，毎日 1 回ずつ，3 日間連続して腹腔 内に注射した。 そして，3群からそれぞれ3〜5匹 ずつ, 感作から 1，2，5 および13週（3月）後に屠 殺し，領域リンパ節（浅および梁腋窩リンパ節なら びに閏径リンパ節）をとり出してスタンプ標本を作 つた.

オートラジオゲラフィーの条件 : スタンプ標本は 直ちにカルノア液にて20分間固定し，80\%エタノー ルにて洗涤後乾燥し, 型の如く Kodak AR-10フィル $\triangle$ (AR-10 Autoradiographic Stripping Plates, Kodak,

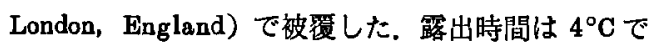
6 週間とし(その間乾燥状態にたもつ), 現像, 定着, 
水洗後， H-E 染色を行なつて検鏡した。

オートラジオグラフの観察方法 : スタンプ標本を 600 1000倍に拡大し, Abbe の描画装置を用いて,
一定区画内のすべての細胞（ほとんどすべてリンパ 球）を描画し，銀粒子をあらわすすのは，核 1 個あ たりの銀粒子の数を核の輪廕内に記入した。

表 1 マウス皮下K BGGと共飞 Complete Fround's' adjuvant (CFA) を 注射した場合, CFA のみの注 射の場合，扰よび生理的食塭水を注射した場合飞，領域リンパ節にあらわれる，ラへルされたり ンパ球の比率、トリチウム・チミシンの最後の注射から1日後 抗原感作後 1 週間

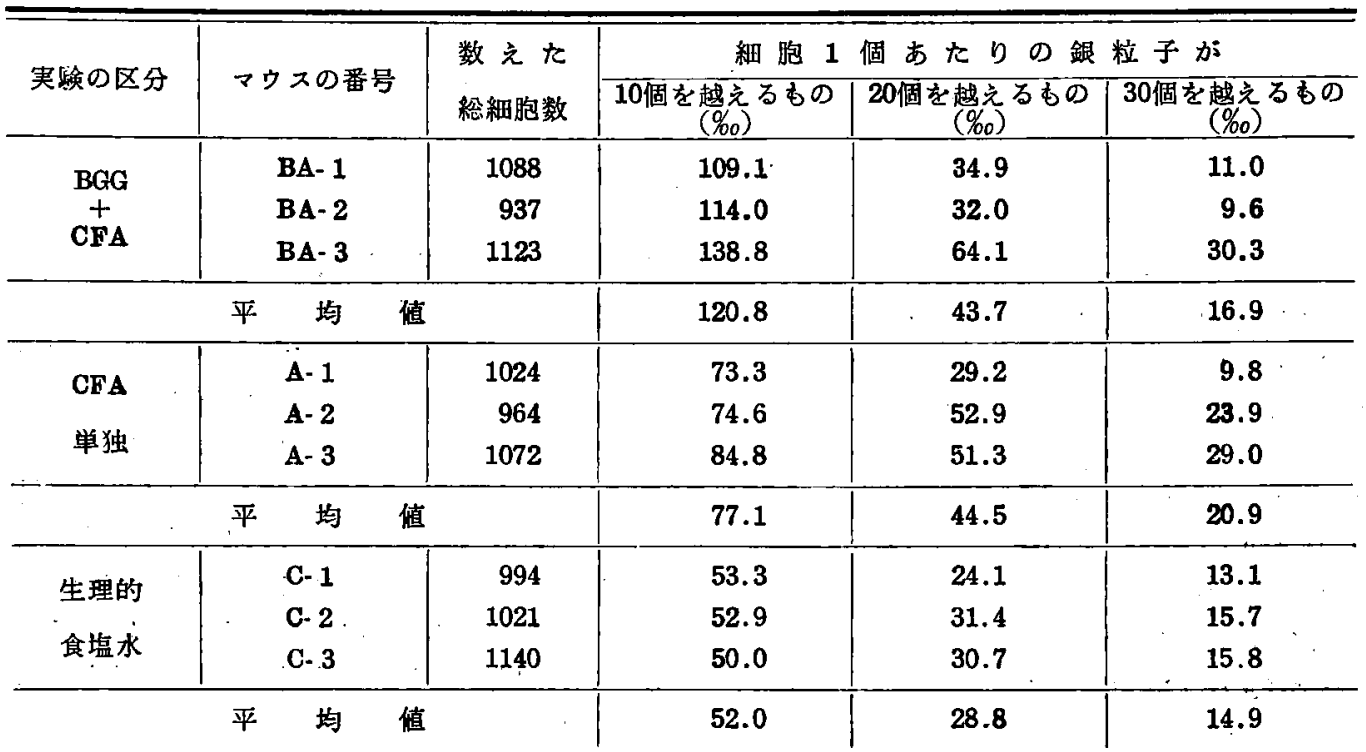

表 2 マゥス皮下飞 BGG と共飞 Complete Freund's adjuvant（CFA）を注射した場合，CFA のみの注 射の場合，拒上び生理的食塭水を注射した場合飞，領域リンハ節にあらわれる，ランルされたリ シパ球の比率、トリチウム・テミシンの最後の注射から1週間後。

抗原感作後 2 週間

\begin{tabular}{|c|c|c|c|c|c|}
\hline \multirow[b]{2}{*}{ 実呀の区分 } & \multirow{2}{*}{ マウスの番号 } & \multirow{2}{*}{$\begin{array}{l}\text { 数えた } \\
\text { 総細胞数 }\end{array}$} & \multicolumn{3}{|c|}{ 細胞 1 個あたりの銀粒子が } \\
\hline & & & 10個を越えるあの & $\begin{array}{c}\text { 20個を越えるむの } \\
(\% 0)\end{array}$ & $\begin{array}{c}\text { 30個を越えるるの } \\
(\% 0)\end{array}$ \\
\hline \multirow{3}{*}{$\begin{array}{c}\text { BGG } \\
+ \\
\text { CFA }\end{array}$} & BA- 5 & 1123 & 45.5 & 19.6 & 6.2 \\
\hline & BA- 6 & 1004 & 45.8 & 18.0 & 8.0 \\
\hline & BA- 7 & 1013 & 45.7 & 22.8 & 7.9 \\
\hline \multicolumn{3}{|c|}{ 均 值 } & 46.2 & 20.1 & 7.4 \\
\hline \multirow{3}{*}{$\begin{array}{l}\text { CFA } \\
\text { 単独 }\end{array}$} & \multirow{3}{*}{$\begin{array}{l}\text { A- } 4 \\
\text { A- } 5 \\
\text { A- } 6\end{array}$} & 1095 & 37.4 & 15.6 & 6.4 \\
\hline & & 1064 & 37.6 & 14.1 & 4.7 \\
\hline & & 1085 & 38.8 & 18.5 & 5.5 \\
\hline \multicolumn{3}{|c|}{ 平 } & 37.9 & 16.1 & 5.5 \\
\hline \multirow{3}{*}{$\begin{array}{l}\text { 生理的 } \\
\text { 食塭水 }\end{array}$} & C- 4 & 1162 & 31.8 & 7.8 & 3.4 \\
\hline & C- 5 & 1082 & 25.0 & 12.0 & 5.5 \\
\hline & C- 6 & 956 & 25.1 & 13.6 & 8.4 \\
\hline \multicolumn{3}{|c|}{ 平均 值 } & 27.3 & 11.1 & 5,8 \\
\hline
\end{tabular}


表 3 マウス皮下K BGG と共飞 Complete Freund'e adjuvant（CFA）を注射した場合，CFA のみの注 射の場合，扣よび生理的食塩水を汇射した場合飞，領域リンパ節にあらわれる，ランルされたり ンバ球の比梁.トリチウム・チミシンの最後の注外から4 週间俊。 抗原感作後 5 週間.

\begin{tabular}{|c|c|c|c|c|c|}
\hline \multirow{2}{*}{ 実験の区分 } & \multirow{2}{*}{ マウスの番号 } & \multirow{2}{*}{$\begin{array}{l}\text { 数えた } \\
\text { 総細胞数 }\end{array}$} & \multicolumn{3}{|c|}{ 細胞 1 個 あ たりの 銀粒子か } \\
\hline & & & $\begin{array}{c}10 \text { 個を越えるるの } \\
(\% \circ)\end{array}$ & 20個を越えるもの & $\begin{array}{c}\text { 30個を越えるもの } \\
(\% \circ)\end{array}$ \\
\hline \multirow{3}{*}{$\begin{array}{c}B G G \\
+ \\
C F A\end{array}$} & BA-13 & 1143 & 35.9 & 13.1 & 6.1 \\
\hline & BA-14 & 1172 & 34.0 & 10.4 & 5.1 \\
\hline & BA-15 & 1023 & 31.4 & 9.8 & 3.9 \\
\hline$\therefore$ & BA-16 & 986 & 51.7 & 26.4 & 11.2 \\
\hline . & 平 & & 38.6 & 16.9 & 6.7 \\
\hline \multirow{3}{*}{$\begin{array}{l}\text { CFA } \\
\text { 単独 }\end{array}$} & A-10 & 1041 & 23.2 & 8.6 & 1.0 \\
\hline & A-11 & 1124 & 17.7 & 4.5 & 1.8 \\
\hline & A.12 & 1107 & 25.5 & 6.3 & 2.9 \\
\hline & 平 均 & & 21.9 & 6.5 & 2.2 \\
\hline \multirow{3}{*}{$\begin{array}{l}\text { 生理的 } \\
\text { 食垭水 }\end{array}$} & C-10 & 1081 & 23.1 & 6.5 & 0.9 \\
\hline & C-11 & 1143 & 23.6 & 11.4 & 2.6 \\
\hline & C-12 & 1355 & 19.2 & 6.4 & 3.7 \\
\hline . & \multicolumn{2}{|l|}{ 平 ： 均 } & 21.9 & 8.2 & 2.4 \\
\hline
\end{tabular}

表 4 マウス皮下に BGG と共に Complete Freund's adjuvant (CFA) を注射した場合, CFAの及の注 射の場合，および生理的食塩水を注射した場合に，領域リンパ節にあらわれる，ラへルされたり ンバ球の比率. トリチゥム・チミシンの最後の注射から13週間（３ケ月）後.

抗原感作後12䓢間

\begin{tabular}{|c|c|c|c|c|c|}
\hline \multirow{2}{*}{ 実験の区分 } & \multirow{2}{*}{ マリスの番号 } & \multirow{2}{*}{$\begin{array}{l}\text { 数えた } \\
\text { 総稩胞数 }\end{array}$} & \multicolumn{3}{|c|}{ 細胞 1 個 あ たりの銀 粒子が } \\
\hline & & & $\begin{array}{c}10 \text { 個を越えるあの } \\
(\% o)\end{array}$ & $\begin{array}{c}20 \text { 個を戥えるもの } \\
(\% 0)\end{array}$ & $\begin{array}{c}\text { 30個を越光るもの } \\
(\% 0)\end{array}$ \\
\hline \multirow{5}{*}{$\begin{array}{c}\text { BGG } \\
+ \\
\text { CFA }\end{array}$} & BA-17 & 977 & 15.3 & 9.2 & 4.1 \\
\hline & BA-18 & 676 & 19.2 & 13.3 & 7.4 \\
\hline & BA-19 & 872 & 22.9 & 14.9 & 10.3 \\
\hline & BA-20 & 822 & 15.8 & 12.2 & 9.7 \\
\hline & $\therefore$ BA-21 & 733 & 23.1 & 16.4 & 9.5 \\
\hline & 均 & & 19.0 & 13.2 & 8.2 \\
\hline \multirow{4}{*}{$\begin{array}{l}\text { CFA } \\
\text { 単独 }\end{array}$} & A-13 & 1000 & - & - & 一 \\
\hline & A.14 & 1205 & - & 5.0 & 4.3 \\
\hline & A-15 & 1018 & - & 3.0 & 2.0 \\
\hline & 均 & & - & 2.7 & 2.1 \\
\hline \multirow{3}{*}{$\begin{array}{l}\text { 生理的 } \\
\text { 食塩水 }\end{array}$} & C-13 & 1000 & - & - & - \\
\hline & C-14 & 997 & - & 2.0 & 1.0 \\
\hline & C-15 & 1060 & - & 3.8 & 2.8 \\
\hline & 平 & & - & 1.9 & 1.2 \\
\hline
\end{tabular}


表 5 表 1 より表 4 までの平均值だけをとりだしてまとめたもの

\begin{tabular}{|c|c|c|c|c|c|c|}
\hline & & & 1 䓢 後 & 2 週 後 & 5 䓢 後 & 13 週 後 \\
\hline $\begin{array}{c}\text { BGG } \\
+ \\
\text { CFA }\end{array}$ & $\begin{array}{l}\text { 細 } \\
\text { 胞 }\end{array}$ & $\begin{array}{l}\text { 10個を越えるむの（\%o） } \\
\text { 20個を越えるむの } \\
\text { 30個を越えるむの }\end{array}$ & $\begin{array}{r}120.8 \\
43.7 \\
16.9\end{array}$ & $\begin{array}{r}46.2 \\
20.1 \\
7.4\end{array}$ & $\begin{array}{r}38.6 \\
16.9 \\
6.7\end{array}$ & $\begin{array}{r}19.0 \\
13.2 \\
8.2\end{array}$ \\
\hline $\begin{array}{l}\text { CFA } \\
\text { 単独 }\end{array}$ & $\begin{array}{l}\text { お } \\
\text { た } \\
b \\
\sigma \\
\text { 鋇 }\end{array}$ & $\begin{array}{l}\text { 10個を越えるもの } \\
\text { 20個を越えるもの } \\
30 \text { 個を越えるむの }\end{array}$ & $\begin{array}{l}77.1 \\
44.5 \\
20.9\end{array}$ & $\begin{array}{r}37.9 \\
16.1 \\
5.5\end{array}$ & $\begin{array}{r}21.9 \\
6.5 \\
2.2\end{array}$ & $\begin{array}{l}- \\
2.7 \\
2.1\end{array}$ \\
\hline $\begin{array}{l}\text { 生理的 } \\
\text { 食塩水 }\end{array}$ & $\begin{array}{l}\text { 粒 } \\
\text { 子 } \\
\text { מ́ }\end{array}$ & $\begin{array}{l}\text { 10個を越えるもの } \\
\text { 20個を越えるもの } \\
30 \text { 個を越えるすの }\end{array}$ & $\begin{array}{l}52.0 \\
28.8 \\
14.9\end{array}$ & $\begin{array}{r}27.3 \\
11.1 \\
5.8\end{array}$ & $\begin{array}{r}21.9 \\
8.2 \\
2.4\end{array}$ & $\begin{array}{l}- \\
1.9 \\
1.2\end{array}$ \\
\hline
\end{tabular}

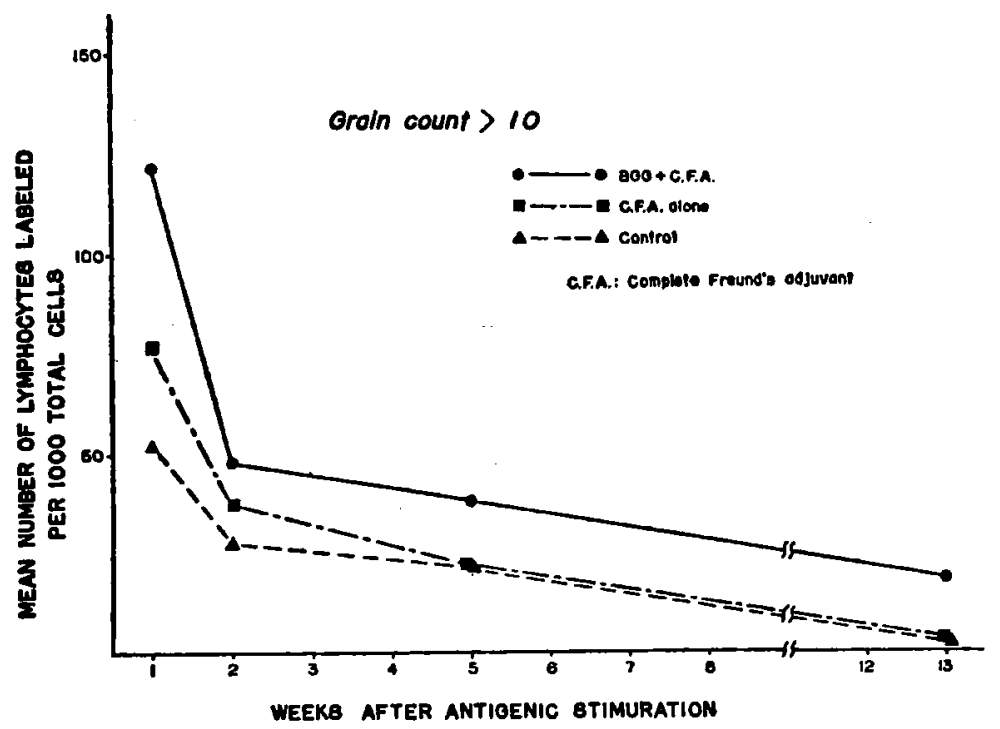

図 1 感作リンパ球のうち，核 1 個あたりの銀粒子の数が10以上のものの千 分比の経日的減少.

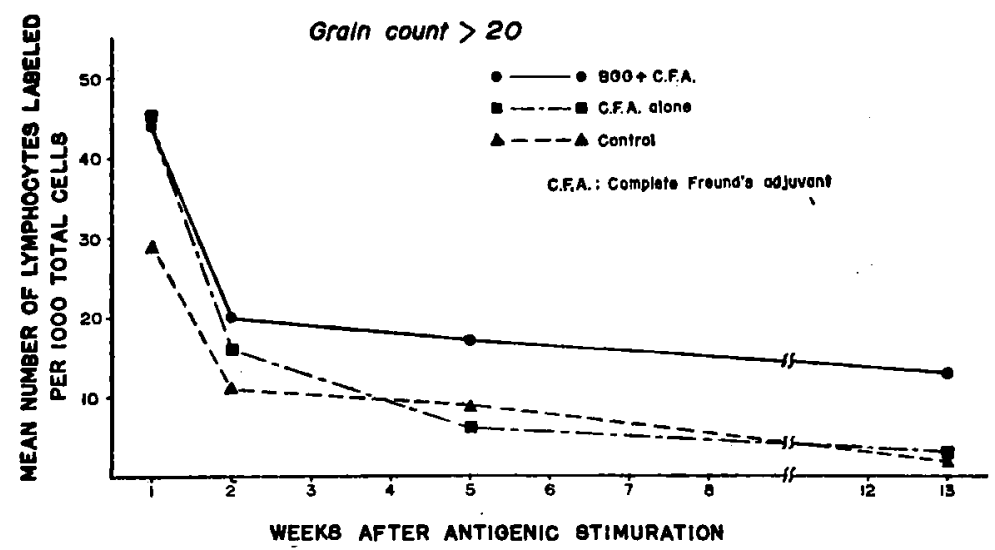

図 2 感作りンパ球のうち，核 1 個あたりの銀粒子の数が20以上のものの千 分比の経日的诚少。

\section{III. 実験成縝と考实}

本実験の主要な成績は， 表 1 - 5 およひ図 $1-3$ にまとめた，本実験の主 旨は，抗原剌激に応じて 堌殖したリンパ球（感作 リンパ球）の寿命を追求 するにあるが，まずTTH でラベルされた感作リン 八球のうち，核 1 個あた りの銀粒子の数が10以上 のリンパ球についてみる と，図 1 に示す如く， ラ バルされたリンパ球の干 分比が TTH の最後の注 射加ら 1 週間（抗原刺激 後 2 週間）で著减するが, その後はゆるやかに減少 する.とこで注目すべき ことは， Freund の完全 アジュバント単独注射の 場合でも，注射から1週 間後にはラベルされたり ンパ球の千分比が，生理 的食塩水を注射した対照 例におけるよりる著しく 高いが，その後比較的す みやかに減少して，TTH の最後の注射から 4 週間 後（抗原刺激加ら5 週間 後）には，生食水対炤例 


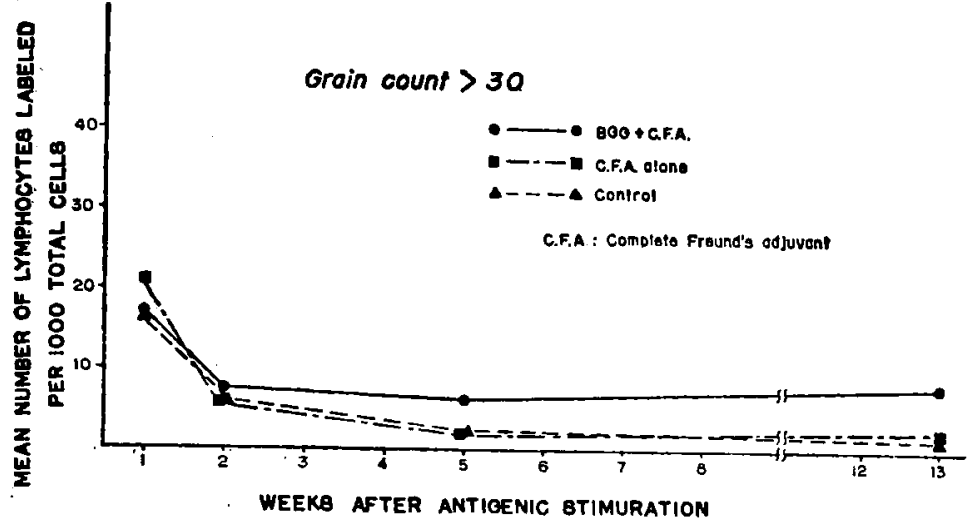

因 3 感作リンパ球のうち, 核 1 個あたりの銀粒子の数が30以上のむのの 千分比の経日的減少。
におけるとほぼ同じ值を示す．てれに対して，BGG と Freund の完全アジュバントを注射した場合には ラベルされたリンパ球の千分比が著しく高い，ての 差は抗原（BGG）の存否以よる差であつて，抗原 （BGG）に対応する感作りンパ球の千分比をあらわ すあのである. そして，ての差は TTH の最後の注 射から12週間 ( 3 月後) においてもはぼ不変であつ た.

次に，核 1 個あたりの銀柆子の数が20以上のリン 八゚球の千分比についてみると，図2にみられるよう K, BGG と Freund の完全アジュバントを注射し た場合と，Freund の完全アジュバント単独注射の 場合ならびに生理的食塩水を注射した場合との間に， TTH の最後の注射加 4 週間以後 (抗原刺激から 5 週間以後）に明瞭な差があらわれる。また，核 1 個あたりの銀粒子の数が 30 以上のリンパ球の百分比 についてみても，ほほ同様である（図3）

上述のいずれの場合においても，TTH の最後の 注射加 3 月後（抗原注射加らあほほ 3 月後）にな ると，抗原に対応する感作リンパ球のうちで寿命の 長いものの千分比がほぼ安定してくる．またての時 期になると，抗原刺激を加えない場合においても (Freund の完全アジュバントの単独注射ならびに生 理的食塩水注射の場合においても）出現するところ のラベルされたリンパ球の千分比が著しく低下す る.

上述の如く，抗原に対応する感作リンパ球のうち には，寿命の長いものがかなり多数あるが， ТTH をとりこんだリンパ球か死減，崩罗して TTH を遊 離し，そのTTH が他のリンパ球にとりこまれる可 能性, すなわち DNA 再利用の可能性が Robinson
らあによよつて指適されて いる. しかし，そのよう な再利用の場合には， T TH が著しく稀釈される ために，リンパ球の核 1 個あたりの銀粒子の数が すくなく，10個を越える ことはまずないむのと思 われる. したがつて，核 1 個ちたりの銀粒子の数 が20以上の場合，より䇴 密にいえば30以上の場合 には，上述の再利用の可 能性を除外して差支えな

いと思われる。

てのようにみてくると，核 1 個あたりの銀粒子の 数が30以上のリンパ球でしかあ寿命の長いリンパ球 について，BGG と Freund の完全アジュバントを 注射した場合の千分比加ら Freund の完全了ジュバ ント単独注射の場合の千分比を差引けば，それが抗 原 (BGG) 飞対応する寿命の長い感作リンパ球と いうことになる，その值を TTH の最後の注射から 12週間後について計算すると，全リンパ球の $6.1 \%$ となる。このような寿命の長い感作リンパ球は免疫 情報を伝達する，いわ泌る“免疫学的記憶細胞”

(immunological memory cell) と推定されるが，む し免疫情報がリンパ球の核 DNA 亿組みこまれてい ると仮定すれば，必ずしも記憶細胞の寿命が長い ことは必要ではない，というのは, 記憶細胞が増殖 してあ，DNA の復製に異状さえなりれば差支えな い管だからである。しかしまた，リンパ球の寿命が 長いととと免度学的記憶との間には密接な関保があ ると考えても差支えないわけで, Fitzgerald (1964)6) はその方がより合理的であると述へている。

\section{N. 桔語}

成熟マウスの体幹皮下にウシの GG） $3 \mathrm{mg}$ を Freund の完全アジュバント $0.4 \mathrm{ml}$ とともに注射し，第 5，6，7 日目に ${ }^{3} \mathrm{H}$-thymidine （TTH）を体重 $1 \mathrm{~g}$ あたり $0.5 \mu \mathrm{c}$ の割合で注射し， 領域リンパ節内におりる TTH でラべルされたリン パ球の千分比を経日的に調へた，別に対照実験とし て，Freund の完全アジュバントならびに生理的食 塩水を単独に注射して，上記と同様の実験を行な? た 
本実験は，抗原（BGG）の刺激によつて増殖した リンパ球(すなわち留作リンパ球)のうちで，青命の 長いあのが免投情報を伝達する記憶細胞 (memory cell）であるまいかという想定のもとに行なつたも

文

1）尾貥越文克：リンパ球の回転とリンパ腺の構 造. 白本臨床, $22: 2333-2341,1964$.

2）尾曾越文竞：リンパ球の動態，とく抗原刺激 凡対寸る増殖反心（第75回岡山医学会総会特別 講演). 岡山医誌, 78別巻：1-16, 1966.

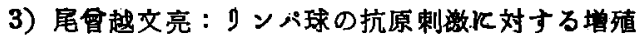
反応，日本医事新報，42:9-12，1965.

4) Osogoe, B.: Kinetics of immune sellular proliferation of lymphocytes in lymph node. Acta Path. Jap. (in preparation).
のであるが，実験の結果，抗原に対応する寿命の長 い感作リンパ球が，抗原刺激を加えてから 3 月後に おいても,リンパ球1000個につきおよそ6個の割合 で出現するととが明らかにされた。

献

5) Robinson, S. H., Brecher, G., Lourie, I. \$. and Haley, J. E. : Leukocyte labelling in rats during and after continuoas infusion of tritiated thymididine: Implications for lymphocyte longevity and DNA reutilization. Blood, 26: 281295, 1965.

6) Fitzgerald, P. H. : The immunologic\$l role and long life-span of small lymphocytes. J. Theoret. Biol., 6: 13-25, 1964.

\title{
Cytodynamics of Sensitized Lymphocytes
}

\section{by}

\section{Life-span of Sensitized Lymphocytes}

\author{
Akinobu Yamamoto \\ Iot Department of Anatomy (Director: Prof. B. Osogoe). \\ and Department of Orthopedic Surgery (Director: Prof. T. Kodama) \\ Okayama University Medical School
}

Mice were sensitized with bovine gamma globulin and complete Freund's adjurant and had received tritiated thymidine at 5, 6, 7 days after the immunization. Among sensitiated lymphocytes in the draining lymphnodes, some had long life-span more than 3 "months. Such long-lived, sensitized lymphocytes were estimated to be about $0.6 \%$ of total lymphooytes in the lymph nodes. 